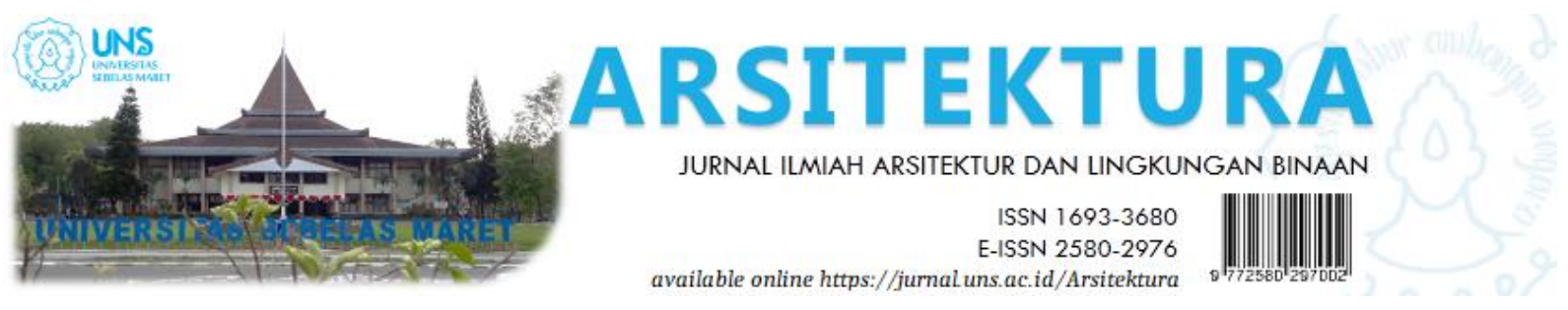

Volume 18 Issue 1 April 2020, pages: 27-42

\title{
Kondisi Thermal Masjid Al-Fairus Pekalongan
}

\section{Thermal Condition of Al-Fairus Pekalongan Mosque}

\author{
M. Ainut Taqwim $\mathbf{S}^{1 *}$, Gagoek Hardiman ${ }^{2}$, Wahyu Setia Budi ${ }^{3}$ \\ Department of Architecture, Engineering Faculty,Diponegoro University ${ }^{1 *}$ \\ Email : ainutza@yahoo.com* \\ Department of Architecture, Engineering Faculty,Diponegoro University ${ }^{2}$ \\ Department of Physics, Faculty Of Science and Mathematics, Diponegoro University ${ }^{3}$
}

DOI: https://doi.org/10.20961/arst.v18i1.31418

Received: June 26, 2019 Revised: December 16,2019 Accepted: October 5,2019 Available online:April 30. 2020

\begin{abstract}
Alfairus Mosque is a mosque that has a design concept that adopts the design of the Nabawi mosque. The building that adopted the design of the Nabawi mosque in Medina has a characteristic high and wide openings on the outer facade with a combination of arch ornaments like most Persian mosque designs. This research focuses on the effect of openings and air movement in space which is a variable used to measure thermal comfort. In the implementation of this research, the existing measurements were carried out when there were no worship activities and measurements when there were worship activities. From the results of the study it was found that the temperature difference was very significant when data collection was in a condition without worship and there were worship activities. In data collection when empty conditions were taken at 10:00 WIB and at the time of worship activities were taken at the time of the Friday prayer service. When empty conditions are obtained the highest effective temperature is $27.80^{\circ} \mathrm{C}$, while during worship services the highest effective temperature reaches $32.20^{\circ} \mathrm{C}$. And at the highest temperature at each measuring point is the location of the center of the mosque where the location of the measuring point is far from the opening or hole of the mosque. While the lowest temperature is at the location close to the opening of the wall hole where the wind blows from that direction. In this study the lowest temperature was at the north side because at the time of the study the wind blew from the north to the south. Air movement greatly affects the decrease and increase in effective temperature in space, air movement is influenced by openings and wind direction. The higher the air movement the lower the effective temperature.
\end{abstract}

Keywords: thermal comfort, air movement, temperatur effective

\section{PENDAHULUAN}

Menurut Karyono (Karyono, 2000), di dalam arsitektur suatu bangunan harus memenuhi tiga unsur, yaitu pertama, bangunan merupakan produk dari sebuah seni, kedua, bangunan harus memberikan kenyamanan (fisik maupun psikis) kepada pengguna bangunan, ketiga, bangunan harus bisa meminimalisir penggunaan energi. Oleh karena itu suatu produk desain harus memenuhi ketiga kriteria 
tersebut sehingga pengguna bangunan akan merasa nyaman ketika menggunakanya. Dalam penelitian ini, peneliti menitik beratkan kepada kenyamanan fisik khususnya kenyamanan thermal. (Lestari, 2013), menyebutkan pergerakan udara dalam suatu ruangan dengan kecepatan pergerakan udara di bawah $1 \mathrm{~m} / \mathrm{dt}$ menimbulkan rasa pengap terhadap kondisi ruangan, sedangkan pergerakan udara dengan kecepatan sampai $1 \mathrm{~m} / \mathrm{dt}$ menjadikan ruangan terasa nyaman, tetapi jika dalam suatu ruangan pergerakan udara memiliki kecepatan diatas lebih dari $1 \mathrm{~m} / \mathrm{dt}$ dapat menimbulkan suasana tidak nyaman dan harus mendapatkan perlakuan khusus terhadap ruangan. Dalam Sogijanto,(Soegijanto, 1999), tabel kriteria MOM menunjukan bahwa suhu nyaman dalam suatu ruang yaitu sejuk antara suhu $20,5^{\circ} \mathrm{C}$ $22,8^{\circ} \mathrm{C}$, suhu nyaman antara suhu $22,8^{\circ} \mathrm{C}$ $25,8^{\circ} \mathrm{C}$, sedangkan suhu panas dalam kategori nyaman yaitu antara $25,8^{\circ} \mathrm{C}-27,1^{\circ} \mathrm{C}$.

Dan pada (Keputusan Menteri Kesehatan Nomor 261/MENKES/SK/II/1998 Tentang: Persyaratan Kesehatan Lingkungan Kerja, 1998) menyatakan bahwa suhu ruanggan nyaman adalah suhu ruangan antara $18^{\circ} \mathrm{C}$ $26^{\circ} \mathrm{C}$. Pada penelitian yang dilakukan (Damastuti \& Nasihien, 2017) meyatakan bahwa pergerakan angin dalam ruangan dipengaruhi oleh orientasi bangunan dan tata letak ventilasi atau lubang dinding. Sehingga udara bersih dan sehat dari luar dapat menggantikan udara di dalam ruangan sehingga menjadikan hunian yang sehat. Begitu pula penelitian yang telah dilakukan oleh (Webb, 2013) bahwa keefektifan ventilasi dalam suatu ruangan sangat mempengaruhi kenyamanan thermal pada ruang tersebut karena dalam sistem tata udara dalam ruangan kenyamanan thermal tidak lepas dari variabel suhu efektif dan pergerakan udara. Sedangkan pada penelitian yang telah dilakukan oleh (Amin, 2004) melakukan penelitian dengan kalkulator PMV dengan pengambilan data pada saat sholat dzuhur dan hasil menyatakan bahwa pada suhu efektif ruangan terdapat suhu yang tidak nyaman tetapi sebanyak $92 \%$ responden merasa nyaman. Hal tersebut dimungkinkan karena orang-orang daerah tropis lebih dapat menerima keadaan lebih panas.Pada penelitian-penelitian yang telah diuraikan diatas banyak tertumpu pada kenyamanan thermal yang hanya fokus pada kondisi eksisting bangunan saja. Walaupun memiliki kesamaan mengenai variabel yang digunakan. Penelitian tersebut banyak mengekspose tentang jenis bukaan dan pergerakan udara dalam ruang baik menggunakan pengukuran lapangan ataupun dengan simulasi software. Tetapi pada saat pengambilan data lapangan sebagian besar tidak melibatkan aktifitas ibadah di dalamnya. Masjid Al-Fairus sebagai objek penelitian memiliki desain masjid yang mengadopsi dari desain Masjid Nabawi. Dimana perkembangan sejarah arsitektur islam untuk desain masjid nabawi sendiri termasuk kedalam desain masjid dengan arsitektur persia. Dalam penelitian (Sutrisno et al., 2013) yang menyatakan bahwa sejarah awal Persia meliputi negara Persia dan juga negaranegara tetangganya yang mempunyai persamaan dalam kebudayaan dan bahasa. Ketika itu, negara-negara ini diperintah oleh kekaisaran-kekaisaran seperti Media dan Akhemenid. Sassania adalah kekaisaran Persia terakhir sebelum kedatangan Islam. Kemudian Persia bergabung menjadi sebagian khilafah Islam awal. Sejarah Iran khusus pula dimulai dengan dinasti Zand pada abad ke-16. Sehingga gaya arsitektur islam pada saat ini banyak mengadopsi dari arsitektur islam persia. (Othman \& Zainal-Abidin, 2011) menyebutkan bahwa karakteristik arsitektur islam pada masa awal kejayaanya adalah polapola geometris tak terbatas. Dimana pola geometris tidak terbatas menggambarkan keagungan dan kebesaran Allah SWT dengan ketidak terbatasan kekuasaanya.

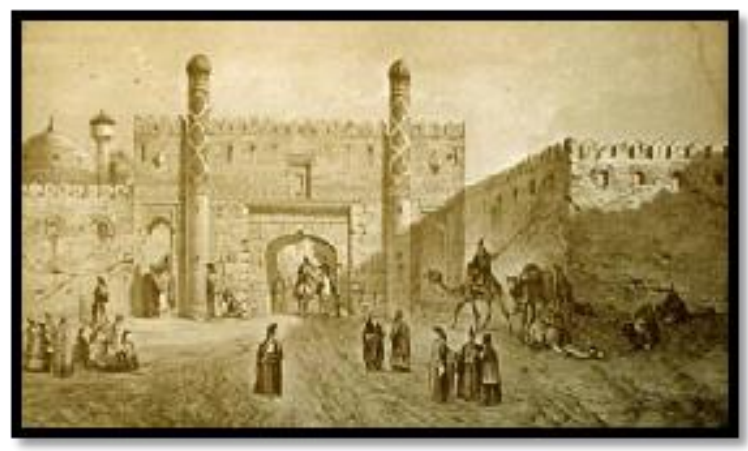

Gambar 1. Masjid era Raja Safawi Abbas I Sumber : Google Image 
Menurut (Rony, 2014) pada sebagian besar desain masjid di persia memiliki kombinasi bidang-bidang geometris atau disebut iwan. Iwan yaitu bidang persegi yang besar bagaikan sebuah dinding gerbang dihiasi dengan lengkungan besar berbentuk seperti bawang terpancung yang biasanya dihiasi dengan kaligrafi,ornamen islami, tegel atau granit mengkilap dan desain geometris. Dari berbagai ciri tersebut juga memiliki ciri lain yaitu pilar motif bata, lengkungan motif bata, menara kembar, dan kubah yang megah.

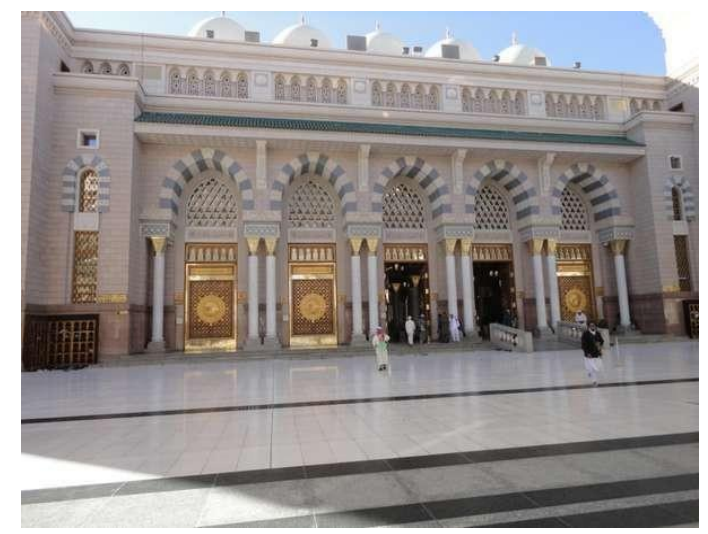

Gambar 2. Tampak Depan Masjid Nabawi Sumber : Google Image

Bagian masjid nabawi seperti gambar di atas merupakan kombinasi antara bidang persegi dengan bidang lengkung yang merupai bawang terpancung dihiasi oleh motif bata pada lengkunganya. Bukaan dinding yang tinggi dan lebar dengan ketinggian dinding diatas rata-rata bangunan standar semakin memudahkan aliran udara yang masuk ke dalam ruang masjid sehingga dapat mempengaruhi kenyamanan thermal dalam ruang masjid tersebut.

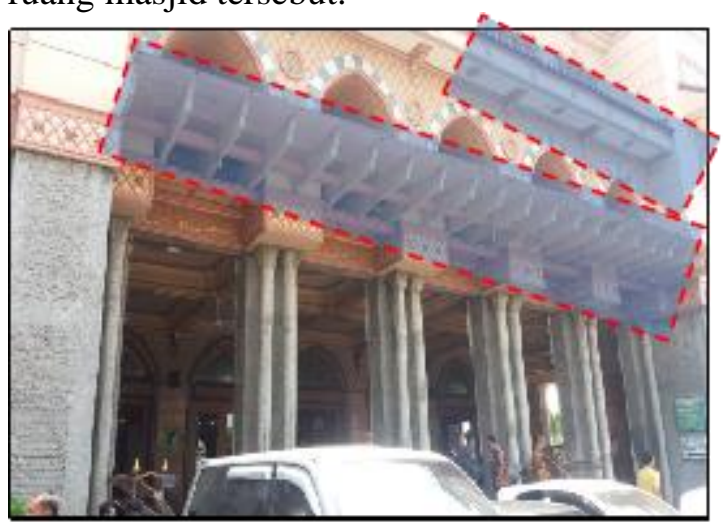

Gambar 3. Tampak Depan Masjid Al fairus
Masjid Al-Fairus memiliki kemiripan dengan Masjid Nabawi baik dari segi ornamen, bentuk pilar dan motif bata pada lengkunganya. Tetapi sudah dimodifikasi dengan menyesuaikan kondisi iklim di kota pekalongan dengan menambahkan semacam tritisan untuk mengantisipasi tampias air ketika hujan. Ketinggian bukaan dinding pada serambi dan bukaan jendela maupun pintu masjid berukuran sangat besar untuk keindahan dari segi estetika dan sebagai sirkulasi udara. (Othman \& Zainal-Abidin, 2011) menyebutkan peran masjid tidak hanya sekedar tempat ibadah dan simbol arsitektur islam tetapi harus memenuhi kebutuhan psikologis penggunanya. Yaitu dengan membuat berbagai kenyamanan yang dipadukan dengan desain arsitektur untuk memanjakan penggunanya.

Pada penelitian lain yang sudah dilakukan oleh beberapa peneliti sebelumnya mengenai kenyamanan thermal masjid diatas, banyak menitik beratkan pada sistem penghawaan alami pada masjid dengan menitik beratkan penelitian pada luas atau besar kecilnya bukaan yang ada pada masjid. Dengan analisa dan simulasi menggunakan software tertentu tetapi penelitian tersebut hanya meneliti objek bangunan pada saat kondisi masjid kosong atau tidak ada aktifitas ibadah. Oleh karena itu peneliti mengadakan penelitian terkait dengan kenyamanan thermal masjid dengan melakukan penelitian pada saat masjid tidak ada aktifitas ibadah dan ketika masjid ada aktifitas ibadah. Variabel yang digunakan pada pengambilan data penelitian adalah suhu lapangan, kelembaban, dan pergerakan udara. Jadi penelitian ini akan meneliti dua kondisi yaitu pada masjid kosong dan saat ada aktifitas ibadah dengan keadaan sperti yang digunakan saat ibadah sholat sehari-hari dengan fasilitas yang telah ada digunakan sebagaimana keseharianya. Tujuan dari diadakanya penelitian ini yaitu untuk mengetahui kenyamanan thermal Masjid $\mathrm{Al}$ Fairus Pekalongan saat kondisi tidak ada ibadah dan kondisi sedang ada aktifitas ibadah. Dengan menggunakan elemen-elemen klimatologi yaitu :

a. Temperatur udara (air temperature)

b. Kelembaban relatif (relative humidity)

c. Pergerakan udara (air movement) 
Manfaat penelitian ini adalah untuk mengetahui kondisi kenamanan thermal Masjid AL Fairus saat tidak ada ibadah dan saat ada ibadah. Dan diharapkan dapat bermanfaat bagi pengembangan Masjid Al Fairus kedepanya dan dapat bermanfaat bagi perkembangan ilmu arsitektur tropis di Indonesia mengenai perencanaan ataupun penerapan ilmu arsitektur bangunan khususnya masjid.

\section{METODE}

Rancangan penelitian ini menggunakan pendekatan kuantitatif karena melakukan pengukuran terhadap objek penelitian. Berdasarkan penelitian dilakukanya pengukuran iklim mikro (Ruang Sholat di Dalam Masjid Al Fairus) dan kenyamanan thermal di Masjid Al Fairus pada 2 penelitian yaitu saat masjid kondisi kosong dan pelaksanaaan sholat jumat.

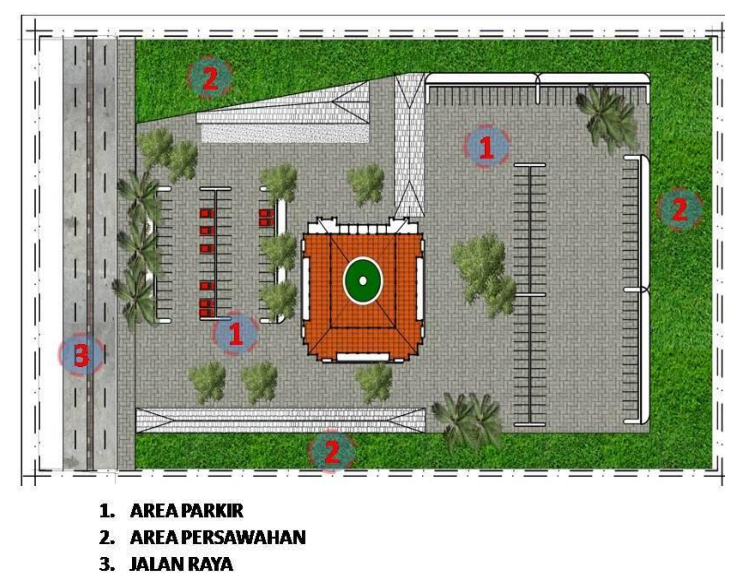

Gambar 4. Site Plan Masjid Al Fairus

Masjid Al-Fairus merupakan masjid yang berdiri di daerah perkotaan, menurut (Abdullah, Majid, \& Othman, 2016) masjid yang berada di daerah perkotaan harus sangat memperhatikan faktor kenyamanan thermal dengan memenfaatkan sirkulasi udara alami untuk efisiensi dalam penggunaan energi. Karena di daerah perkotaan kebanyakan vegetasi semakin sedikit dan suhu udara lebih tinggi. Dari gambar site plan kondisi tapak dari objek penelitian yaitu Masjid Al-Fairus berada di area halaman yang sangat luas, sisi utara adalaha area hamparan luas persawahan, sisi selatan adalah jalan raya yang merupakan jalan utama pantura semarang-jakarta. Dengan kondisi tapak seperti ini potensi hembusan angin atau sangat tinggi, tetapi untuk pergerakan udara dalam ruang dipengaruhi oleh desain bangunan dan bukaan lubang dinding.

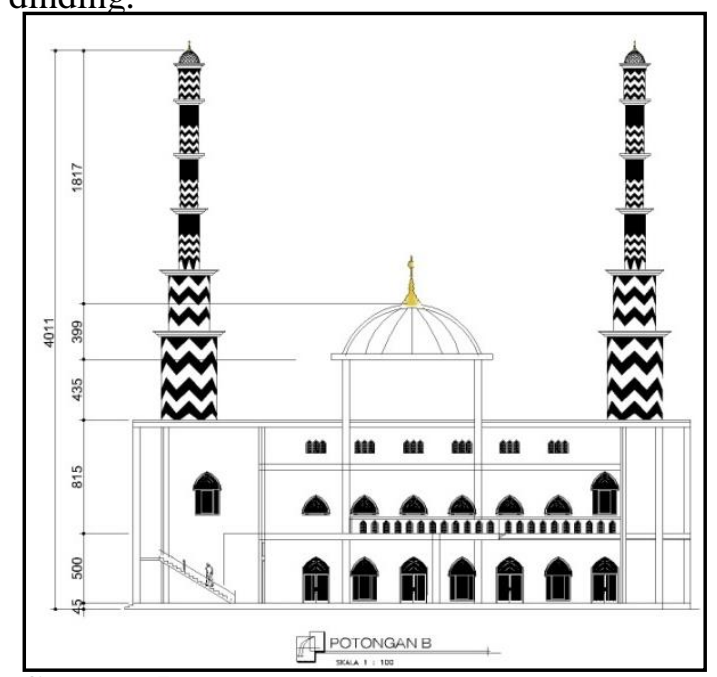

Gambar 5. Potongan Melintang Masjid Al Fairus

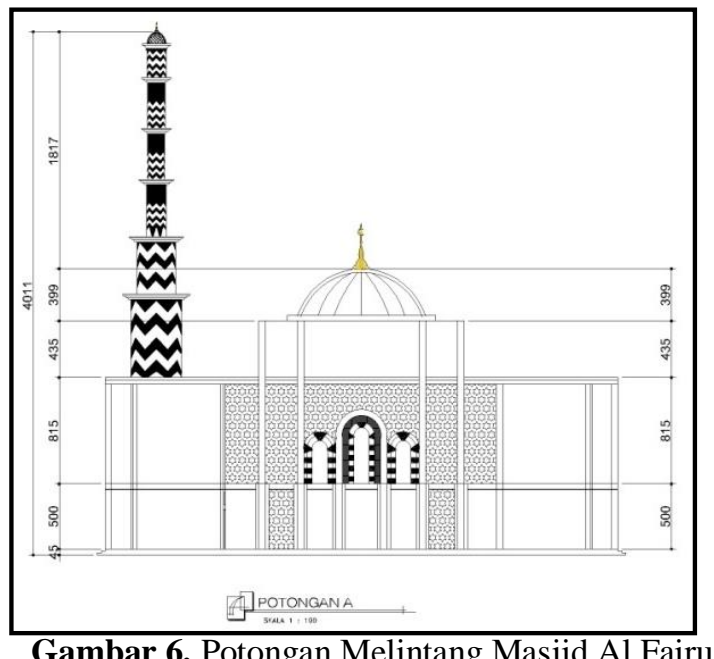

Dari gambar potongan Masjid al-fairus ini terdapat banyak bukaan baik di lantai satu ataupun lantai 2. Ketinggian antara lantai 1 dan 2 cukup tinggi dan lantai 2 memiliki ketinggian yang lebih tinggi sehingga memudahkan aliran udara yang mengalir dalam masjid. 


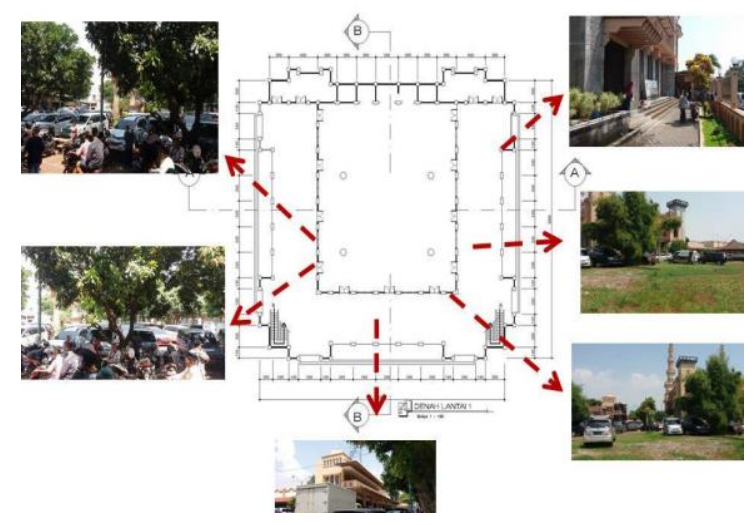

Gambar 7. Kondisi Eksisting di Luar Masjid

Kondisi eksisting di luar masjid Al-Fairus terdapat bebrapa pepohonan yang berjajar di area parkir sebelah sisi selatan yang juga berfungsi sebagai peneduh untuk area parkir, sedangkan sisi utara merupakan hamparan lahan parkir yang sangat luaas di tepi area persawahan sehingga kecepatan angin di area luar masjid cukup tinggi. Hal itu jjuga dapat mempenngaruhi kondisi thermal di dalam masjid.

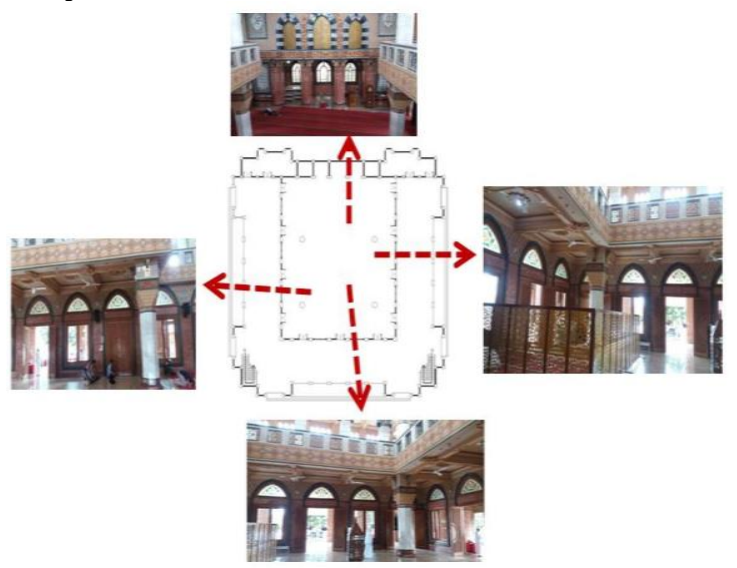

Gambar 8. Kondisi Eksisting di Dalam Masjid

Untuk kondisi di dalam Masjid Al-Fairus pada lantai satu terdapat pintu dan jendela yang kesemuanya dapat di buka dan di tutup tutup. Pintu di buka sebagai akses pintu masuk ke dalam masjid, sedangkan jendela di buka untuk ventilasi udara agar suhu udaradi dalam masjid tidak terlalu tinggi.

Dari deskripsi objek yang telah disampaikan diatas yaitu masjid Al-fairus mengadopsi desain masjid nabawi yang berada di madinah. Masjid nabawi didesain untuk iklim tropis kering sedangkan Masjid Al-Fairus mengadopsi desain Masjid Nabawi untuk dibangun di daerah tropis lembab khususnya di Kota Pekalongan. Oleh karena itu peneliti tertarik untuk mengetahui kondisi thermal Masjid Al-fairus saat ada ibadah dan saat tidak ada ibadah.

\subsection{Variabel Penelitian}

Dalam penelitian ini terdapt dua analisa yang saling berkaitan, yang mempunyai pengaruh yang sama. Variabelnya antara lain sebagai berikut :
a. Suhu udara
b. Kelembaban
c. Pergerakan udara

\subsection{Cara Pengumpulan Data}

Pengambilan data dilapanggan dilakukan langsung di lokasi penelitian yaitu Masjid AlFairus pekalongan. Pengambilan data pengukuran terbagi menjadi beberapa bagian antara lain :

a. Pengambilan data eksisting

Yaitu pengambilan data pada saat Masjid Al-fairus tidak ada aktifitas kegiatan ibadah sholat. Pengambilan data ini meliputi pengambilan data di dalam masjid, berjumlah 12 titik ukur.

b. Pengambilan Data Ketika Ada Kegiatan Ibadah Sholat 5 Waktu dan Sholat Jumat.

Pengambilan data saat ada aktifitas ibadah, jumlah total titik ukur pada saat pengambilan data ini adalah 12 titik ukur sesuai dengan kepadatan luasan jamaah shof diambil tiap $4 \mathrm{x}$ 4 meter. Pengambilan data ini adalah pada saat melaksanakan sholat ibadah sholat jumat. Adapun alat ukur yang digunakan adalah alat ukur digital hotwire dan hygrometer yang kemudian dimasukan ke dalam table. Dari data yang diperoleh kita masukan ke dalam tabel dengan dihubungkan dengan diagram psychometric untuk mencari temperatur efektifnya. Data yang diambil antara lain,:

a. Data suhu ruangan

b. Data kelembaban ruangan 


\subsection{Cara Memperoleh Data}

Dalam pengambilan data penelitian ini dilakukan dengan dua metode yang berbeda yaitu :

\section{a. Primer}

Data penelitian untuk mengambil data suhu, kelembaban, dan pergerakan angin di dalam masjid saat waktu pelaksanaan ibadah sholat jumat. Waktu pengukuran atau pengambilan data penelitian ini dimulai pada saat dalam masjid mulai terisi penuh dan pengambilan data mulai dilakukan saat khotib sedang berkhutbah. (Waktu Pelaksanaan Sholat jumat pukul 11.30 WIB).

\section{b. Skunder}

Data penelitian untuk mengambil data suhu, kelembaban, dan pergerakan angin di dalam masjid tanpa adanya aktifitas sholat . yaituWaktu Pengambilan Data Siang pukul 10.00 WIB.

\subsubsection{Cara Menganalisa}

Pengambilan data lapangan di Masjid Al-fairus untuk di dalam masjid terdapat 12 titik ukur. Adapun dasar pengambilan lokasi titik ukur dalam masjid adalah seperti gambar berikut :

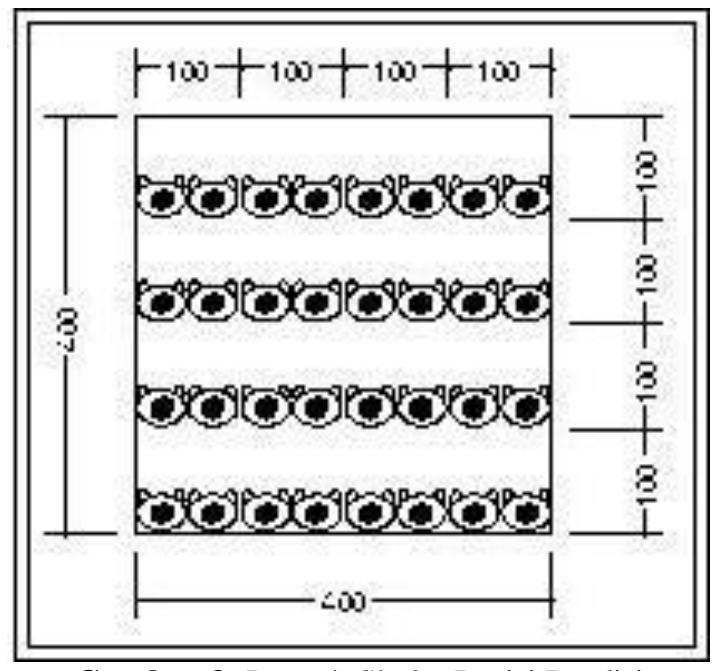

Gambar 9. Jamaah Sholat Posisi Berdiri

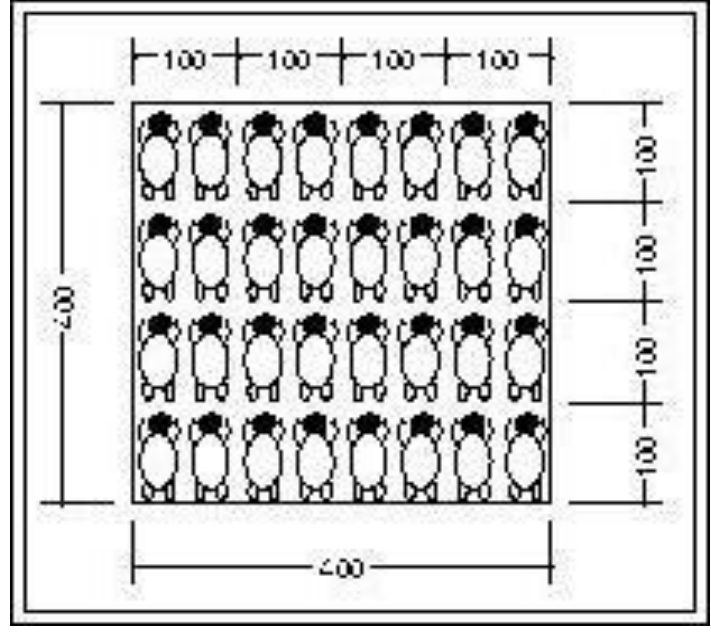

Gambar 10. Jamaah Sholat Posisi Sujud

Menurut (Amin, 2004) Untuk standar ideal ukuran shof posisi sholat berjamaah adalah 50 $\mathrm{cm}$ untuk satu jamaah atau untuk ukuran 4 meter x 4 meter dapat menampung jamaah sholat sebanyak 32 orang jamaah.

Untuk menentukan jumlah titik ukur dalam proses pengambilan data penelitian yaitu luasan ruangan dibagi dengan luasan yang dicakup tiap titik ukur yaitu 4 x $4 \mathrm{~m}$. Sehingga didapat sebanyak 12 lokasi titik ukur.

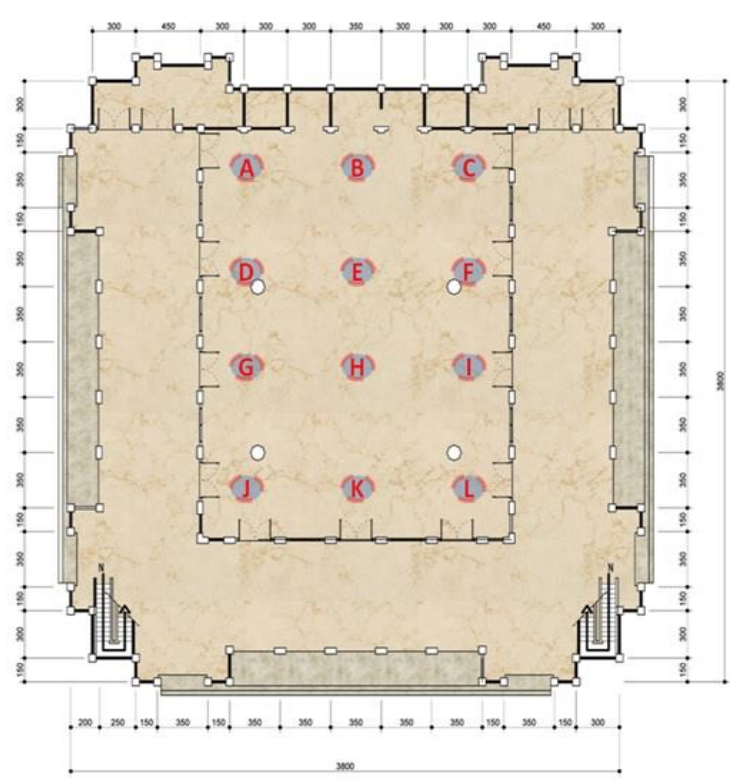

Gambar 11. Lokasi Titik Ukur 


\section{HASIL DAN PEMBAHASAN}

Pada saat melakukan penelitian data eksisting yang telah dilakukan lakukan pada tanggal 23 April 2019 peneliti melakukan pengukuran terkait dengan kondisi eksisting bangunan yang dipakai sesuai keadaan setiap harinya. Adapun data-data yang diperoleh adalah sebagai berikut :

\subsection{Data Penelitian di Masing-masing Titik Ukur Dalam Masjid Tanpa Adanya Aktifitas Ibadah}

Data pengukuran ini diambil pada saat masjid tanpa adanya aktifitas apapun dan sesuai dengan kondisi eksisting keseharian yang dilakukan oleh pihak masjid. Untuk pengukuran dalam masjid terdapat 12 titik ukur yang masing-masing diambil datanya meliputi, suhu, kelembaban, dan pergerakan udara.

Pengukuran untuk pengambilan data ini dilakukan sebanyak 7 kali angka yang muncul di alat hot wire kemudian di rata-rata. Pengambilan data eksisting ini dilakukan pada pukul 10.00 WIB, di masing-masing lokasi titik ukur. Data yang diambil yaitu data suhu, kelembaban, dan pergerakan udara yang nantinya akan disajikan dalam tabel dan grafik.

Tabel 3.1. Data Temperatur Efektif pukul 10.00

WIB

\begin{tabular}{|c|c|c|c|c|c|}
\hline \multirow{2}{*}{ TITIK } & \multicolumn{5}{|c|}{ Temperatur Efektif (TE) ${ }^{\circ} \mathbf{C}$} \\
\cline { 2 - 6 } & 08.00 & 09.00 & $\mathbf{1 0 . 0 0}$ & 14.00 & 16.00 \\
\hline A & 26.03 & 26.72 & 26.22 & 26.86 & 25.61 \\
\hline B & 26.03 & 26.58 & 26.28 & 27.31 & 25.95 \\
\hline C & 26.06 & 26,80 & 26.74 & 26.39 & 25.20 \\
\hline D & 26.16 & 26.72 & 26.42 & 26.96 & 26.03 \\
\hline E & 26.03 & 26.72 & 27.72 & 27.61 & 26.18 \\
\hline F & 25.94 & 26.69 & 26.03 & 26.99 & 25.65 \\
\hline G & 26.03 & 26.72 & 26.72 & 26.97 & 25.56 \\
\hline H & 26.03 & 26.72 & 26.54 & 27.31 & 26.32 \\
\hline I & 26.3 & 26.44 & 26.44 & 26.78 & 25.59 \\
\hline J & 26.09 & 26.80 & 27.80 & 26.99 & 26.18 \\
\hline K & 25.90 & 26.69 & 26.69 & 28.12 & 26.27 \\
\hline L & 25,83 & 26.35 & 26.35 & 26.75 & 25.70 \\
\hline
\end{tabular}

Pada tabel 3.1. temperatur efektif rata-rata di tiap lokasi titik ukur pada pukul 10.00 WIB dengan kondisi masjid kosong dapat terlihat yaitu titik A $\left(26,22^{\circ} \mathrm{C}\right)$; titik B $\left(26,28^{\circ} \mathrm{C}\right)$; titik $\mathrm{C}\left(26,74^{\circ} \mathrm{C}\right)$; titik $\quad \mathrm{D}\left(26,42^{\circ} \mathrm{C}\right)$; titik $\mathrm{E}\left(27.72^{\circ} \mathrm{C}\right)$; titik $\mathrm{F}\left(26,03^{\circ} \mathrm{C}\right)$; titik $\mathrm{G}$ $\left(26,72^{\circ} \mathrm{C}\right)$; titik $\mathrm{H}\left(26,54^{\circ} \mathrm{C}\right)$; titik $\mathrm{I}\left(26,44^{\circ} \mathrm{C}\right)$; titik $\mathrm{J}\left(27,80^{\circ} \mathrm{C}\right)$; titik $\mathrm{K}\left(26,69^{\circ} \mathrm{C}\right)$; titik $\mathrm{L}\left(26,35^{\circ} \mathrm{C}\right)$, terlihat titik ukur paling tinggi temperatur efektifnya adalah titik J. Dimana lokasi titik $\mathrm{J}$ berada di tengah-tengah ruang dan jauh dari bukaan jendela ataupun pintu. Sedangkan temperatur efektif yang paling rendah adalah pada titik $\mathrm{F}$ yaitu $\left(26,03^{\circ} \mathrm{C}\right)$ dimana lokasi titik ukur $\mathrm{F}$ berada di dekat bukaan pintu disisi depan.

Tabel 3.2. Pergerakan Udara Pukul 10.00 WIB

\begin{tabular}{|c|c|c|c|c|c|c|}
\hline \multirow{2}{*}{$\begin{array}{l}\text { TITIK } \\
\text { UKUR }\end{array}$} & \multicolumn{5}{|c|}{ Pergerakan Udara $(\mathrm{m} / \mathrm{s})$} & Arah \\
\hline & 08.00 & 09.00 & 10.00 & 14.00 & 16.00 & \multirow{13}{*}{ 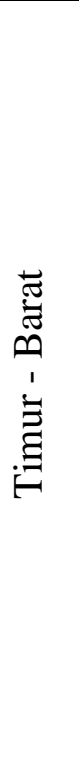 } \\
\hline A & 0.06 & 0.07 & 0.11 & 0.45 & 0.42 & \\
\hline $\mathrm{B}$ & 0.07 & .0 .06 & 0.09 & 0.33 & .0 .30 & \\
\hline $\mathrm{C}$ & 0.14 & 0.12 & 0.04 & 0.77 & 0.72 & \\
\hline $\mathrm{D}$ & 0.10 & 0.09 & 0.07 & 0.41 & 0.38 & \\
\hline $\mathrm{E}$ & 0.05 & 0.10 & 0.05 & 0.24 & 0.29 & \\
\hline $\mathrm{F}$ & $0 . .09$ & 0.14 & 0.14 & 0.40 & 0.45 & \\
\hline G & $0 . .09$ & 0.11 & 0.06 & 0.37 & 0.49 & \\
\hline $\mathrm{H}$ & 0.05 & 0.08 & 0.08 & 0.33 & 0.26 & \\
\hline I & 0.09 & 0.17 & 0.17 & 0.49 & 0.51 & \\
\hline $\mathrm{J}$ & 0.10 & 0.10 & 0.04 & 0.33 & 0.29 & \\
\hline $\mathrm{K}$ & 0.16 & 0.14 & 0.14 & 0.15 & 0.27 & \\
\hline $\mathrm{L}$ & 0.17 & 0.19 & 0.19 & 0.41 & 0.43 & \\
\hline
\end{tabular}

Dari tabel 3.2. dapat terlihat bahwa pergerakan angin dalam masjid tertinggi ada pada lokasi titik ukur L yaitu 0,19 m/dt, dimana lokasi titik ukur L berada pada sisi timur dekat dengan pintu utara dan pintu sisi timur. Sedangkan pergerakan angin terendah adalah di lokasi titik ukur $\mathrm{C}$ yaitu $0,04 \mathrm{~m} / \mathrm{dt}$, dimana lokasi titik ukur $\mathrm{C}$ berada di sisi utara raunagan sholat dalam masjid dekat dengan pintu depan sisi utara. Pada pengukuran ini arah angin berhembus dari arah timur ke arah barat. 


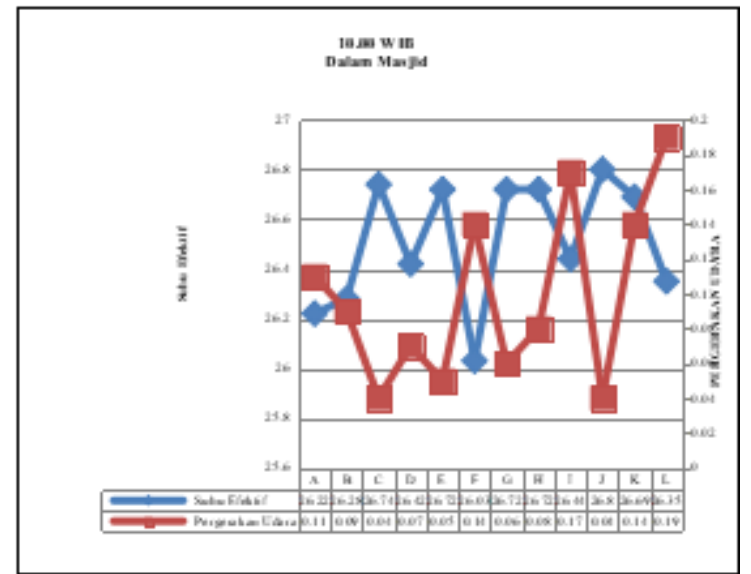

Grafik 3.1. Grafik Hubungan Suhu Efektif Dan pergerakan Udara Pada Pukul 10.00 WIB

Pada grafik 3.1 terlihat pada grafik lokasi titik ukur dengan suhu paling tinggi adalah titik $\mathbf{J}$ memiliki temperatur $26,22{ }^{\circ} \mathrm{C}$ dimana letak titik ukur $\mathrm{J}$ berada di sisi utara timur dekat dengan pintu timur masjid dengan pergerakan udara rata-rata $0.04 \mathrm{~m} / \mathrm{dt}$. Pada lokasi ini di pukul 10.00 WIB dekat dengan serambi sisi utara masjid yang mana pada lokasi tersebut terkena paparan cahaya matahari dari sisi timur dan pada saat itu arah angin berhembus dari arah timur ke arah barat tetapi pada lokasi pengukuran ada dinding serambi dan dinding sisi selatan sehingga lokasi titik ukur ini pergerakan udaranya tidak maksimal. Sedangkan pada titik ukur $F$ memiliki temperatur efektif terendah dengan suhu $26,03^{\circ} \mathrm{C}$ dengan pegerakan udara $0.14 \mathrm{~m} / \mathrm{dt}$. Lokasi ini berada pada sisi utara masjid di depan pintu sisi utara sehingga pergerakan udara paa titik ukur ini cukup tinggi diantara lainya.

\subsection{Data penelitian di masing-masing titik ukur dalam masjid saat pelaksanaan ibadah sholat (sholat jumat)}

Data penelitian ini diambil di masing-masing titik ukur yang sama dengan pengambilan yang dilakukan pada pukul 10.00 WIB dengan tanpa ibadah. Perbedaanya pada penelitian ini dilakukan di saat pelaksanaan ibadah sholat jumat. Pemilihan waktu pada penelitian ini dikarenakan pada saat masuk waktu sholat jumat radiasi matahari berada pada puncak suhu tertinggi dan pergerakan udara di dalam ruangan semakin meningkat disertai dengan aktifitas ibadah sholat jumat dengan kondisi shof penuh dengan jamaah.

Tabel 3.3. Data Temperatur Efektif Waktu Sholat Jumat

\begin{tabular}{|c|c|c|c|c|c|c|}
\hline \multirow{2}{*}{$\begin{array}{l}\text { TIT } \\
\mathrm{K} \\
\mathrm{UKU} \\
\mathrm{R} \\
\end{array}$} & \multicolumn{6}{|c|}{ Temperatur Efektif (TE) ${ }^{\circ} \mathrm{C}$} \\
\hline & Dzuhur & Ashar & Magrib & Isya & Shubuh & Jumat \\
\hline $\mathrm{A}$ & 26.03 & 26.72 & 26.78 & 26.86 & 25.61 & 31.80 \\
\hline B & 26.03 & 26.58 & 26.80 & 27.31 & 25.95 & 32.00 \\
\hline $\mathrm{C}$ & 26.06 & 26,80 & 26.01 & 26.39 & 25.20 & 31.80 \\
\hline D & 26.16 & 26.72 & 26.94 & 26.96 & 26.03 & 31.80 \\
\hline E & 26.03 & 26.72 & 27.00 & 27.61 & 26.18 & 32.20 \\
\hline $\mathrm{F}$ & 25.94 & 26.69 & 26.16 & 26.99 & 25.65 & 31.53 \\
\hline G & 26.03 & 26.72 & 26.24 & 26.97 & 25.56 & 31.48 \\
\hline $\mathrm{H}$ & 26.03 & 26.72 & 27.23 & 27.31 & 26.32 & 32.14 \\
\hline I & 26.3 & 26.44 & 26.38 & 26.78 & 25.59 & 31.22 \\
\hline $\mathrm{J}$ & 26.09 & 26.80 & 27.06 & 26.99 & 26.18 & 31.42 \\
\hline $\mathrm{K}$ & 25.90 & 26.69 & 26.44 & 28.12 & 26.27 & 31.58 \\
\hline $\mathrm{L}$ & 25,83 & 26.35 & 26.85 & 26.75 & 25.70 & 31.34 \\
\hline
\end{tabular}

Pada tabel 3.3. temeratur efektif rata-rata di tiap lokasi titik ukur pada pukul saat sholat jumat dapat terlihat yaitu titik A $\left(31,80^{\circ} \mathrm{C}\right)$; titik B $\left(32,00^{\circ} \mathrm{C}\right)$; titik $\mathrm{C}\left(31,80^{\circ} \mathrm{C}\right)$; titik $\mathrm{D}\left(31,80^{\circ} \mathrm{C}\right)$; titik $\mathrm{E}\left(32,20^{\circ} \mathrm{C}\right)$; titik $\mathrm{F}\left(31,53^{\circ} \mathrm{C}\right)$; titik $\mathrm{G}$ $\left(31,48^{\circ} \mathrm{C}\right)$; titik $\mathrm{H}\left(32,14^{\circ} \mathrm{C}\right)$; titik $\mathrm{I}\left(31,22^{\circ} \mathrm{C}\right)$; titik $\mathrm{J}\left(31,42^{\circ} \mathrm{C}\right)$; titik $\mathrm{K}\left(31,58^{\circ} \mathrm{C}\right)$; titik $\mathrm{L}\left(31,34^{\circ} \mathrm{C}\right)$, terlihat titik ukur paling tinggi temperatur efektifnya adalah titik E. Dimana lokasi titik $\mathrm{E}$ berada di tengah-tengah ruang dan jauh dari bukaan jendela ataupun pintu. Sedangkan temperatur efektif yang paling rendah adalah pada titik I yaitu $\left(31,22^{\circ} \mathrm{C}\right)$ dimana lokasi titik ukur I berada di dekat bukaan pintu disisi Samping. 
Tabel 3.4. Tabel Pergerakan Udara Saat Sholat Jumat

\begin{tabular}{|c|c|c|c|c|c|c|}
\hline \multirow{2}{*}{$\begin{array}{l}\text { Titik } \\
\text { Ukur }\end{array}$} & \multicolumn{5}{|c|}{ Pergerakan Udara (m/s) } & \multirow{2}{*}{\begin{tabular}{|c} 
Arah \\
Angi \\
$\mathrm{n}$
\end{tabular}} \\
\hline & Ashar & $\begin{array}{c}\text { Magri } \\
\text { b }\end{array}$ & Isya & Shubuh & Jumat & \\
\hline A & 0.67 & 0.14 & 0.28 & 0.17 & 0.53 & \\
\hline B & .0 .81 & 0.11 & 0.28 & .0 .22 & 0.39 & \\
\hline $\mathrm{C}$ & 1.01 & 0.07 & 0.31 & 0.27 & 0.94 & \\
\hline D & 0.57 & 0.18 & 0.28 & 0.09 & 0.43 & స్ \\
\hline E & 0.24 & 0.11 & 0.11 & 0.09 & 0.28 & \\
\hline $\mathrm{F}$ & 0.57 & 0.37 & 0.30 & 0.06 & 0.56 & 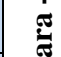 \\
\hline G & 0.24 & 0.16 & 0.21 & 0.25 & 0.35 & \\
\hline $\mathrm{H}$ & 0.37 & 0.07 & 0.06 & 0.10 & 0.19 & \\
\hline I & 0.50 & 0.26 & 0.23 & 0.06 & 0.40 & \\
\hline $\mathrm{J}$ & 0.28 & 0.26 & 0.22 & 0.15 & 0.51 & \\
\hline $\mathrm{K}$ & 0.45 & 0.27 & 0.24 & 0.08 & 0.59 & \\
\hline $\mathrm{L}$ & 0.47 & 0.26 & 0.28 & 0.17 & 0.53 & \\
\hline
\end{tabular}

Dari Tabel 3.4. dapat terlihat pergerakan udara berkisar antara $0,19 \mathrm{~m} / \mathrm{dt}-0,94 \mathrm{~m} / \mathrm{dt}$. Dimana pada pengukuran data waktu sholat jumat terdapat pergerakan angin paling tinggi yaitu pada lokasi titik ukur C yaitu $0,94 \mathrm{~m} / \mathrm{dt}$. Dalam lokasi titik ukur ini berada pada sisi utara masjid dekat dengan pintu utara masjid dengan kondisi kipas angin yang berada diatas titi $\mathrm{C}$ tersebut dalam kondisi menyala. Sedangkan pada pergerakan udara terendah pada lokasi titik ukur berada pada titik ukur $\mathrm{H}$ dengan pergerakan udara $0,19 \mathrm{~m} / \mathrm{dt}$. Dalam kondisi yang penuh dengan jamaah kondisi titik $\mathrm{H}$ berada di tengah-tengah masjid dan jauh dari posisi kipas angin.

Pada grafik 3.2 terlihat pada titik A memiliki temperatur $31,80^{\circ} \mathrm{C}$ dimana letak titik ukur A berada di dekat dengan pintu depan masjid sisi selatan dengan pergerakan udara rata-rata $0.53 \mathrm{~m} / \mathrm{s}$. Sedangkan pada titik ukur C memiliki yang sama yaitu $31,80^{\circ} \mathrm{C}$ tetapi memiliki pergerakan udara yang lebih tinggi yaitu $0,94 \mathrm{~m} / \mathrm{s}$ dikarenakan berada dekat dengan pintu sisi utara masjid yang manan pada saat itu angin berhembus dari utara ke selatan. Untuk titik ukur E memiliki temperatur efektif yang paling tinggi dikarenakan lokasi ini berada di tengahtengah masjid dengan kondisi jamaah shof sholat penuh sehingga temperatur efektif sangat tinggi dibandingkan dengan lainya dan pergerakan udara hanya $0,28 \mathrm{~m} / \mathrm{s}$. Dari grafik hubungan antara suhu efektif dan pergerakan udara dalam ruang sholat Masjid Al-fairus pada saat sholat jumat menunjukan bahwa semakin tingi pergerakan udara maka temperatur efektif akan semakin menurun.

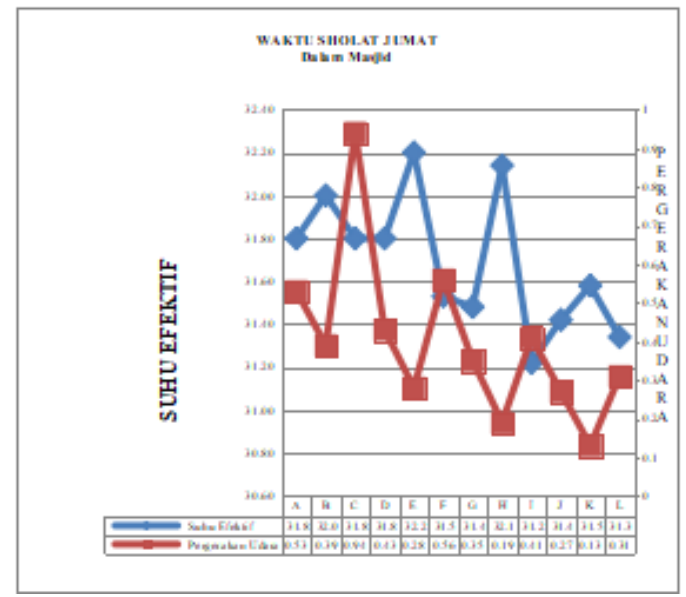

Grafik 3.2. Grafik Hubungan Suhu Efektif Dan pergerakan Udara Pada Saat Sholat Jumat

Dari masing-masing titik ukur menunjukan perbedaan suhu, pergerakan udara dan kelembaban di masing-masing titik ukur yang mempengaruhi temperatur efektif pada masing-masing lokasi titik ukur. Semakin naik suhu efektifnya pasti pergerakan udara di lokasi titik ukur tersebut rendah, sebaliknya semakin tinggi perrgerakan udara di lokasi titik ukur tersebut maka semakin turun suhu efektif di lokasi titik ukur tersebut. Sedangkan pada waktu ada aktifitas ibadah sholat jumat memiliki perbedaan yang cukup signifikan jika dibandingkan suhu efektif saat kondisi masjid kososng pada pukul 10.00 WIB, hal ini karena disebabkan density atau banyaknya jamaah yang melakukan ibadah sholat pada lokasi titik pengukuran juga mempengaruhi suhu pada lokasi titik pengukuraan. Tubuh manusia sendiri melakukan evaporasi atau penguapan metabolisme tubuh sehingga lokasi yang penuh dengan manusia turut mempengaruhi peningkatan di lingkungan tersebut. 


\section{KESIMPULAN}

Data yang diperoleh pada saat pengukuran tanpa adanya aktifitas ibadah pada pukul 10.00 WIB suhu efektif paling rendah adalah $26,03^{\circ}$ $\mathrm{C}$ dan suhu efektif paling tinggi adalah 27,80 ${ }^{\circ} \mathrm{C}$. Kalo dilihat dari tabel kriteria kenyamanan MOM masuk dalam kategori suhu panas dalam kategori nyaman. Dan data yang diperoleh saat pengukuran pada saat ada aktifitas ibadah sholat jumat suhu efektif paling rendah adalah $31,22{ }^{\circ} \mathrm{C}$ sedangkan suhu efektif paling tinggi adalah $32,20^{\circ} \mathrm{C}$. Kalo dilihat dari tabel kriteria kenyamanan MOM masuk dalam kategori tidak nyaman.

Oleh karena itu dapat ditarik kesimpulan kondisi thermal Masjid AL-Fairus saat tanpa ada ibadah pada pukul 10.00 WIB masuk dalam kriteria suhu panas dengan kategori nyaman. Sedangkan kondisi thermal Masjid Al-Fairus saat ada ibadah pada waktu sholat Jumat masuk dalam kategori tidak nyaman.

\section{UCAPAN TERIMA KASIH}

Dengan selesainya penelitian ini peneliti mengucapkan banyak terima kasih kepada seluruh pengurus takmir Masjid Al-fairus pekalongan yang telah membantu memberikan izin penelitian dan memberikan informasi yang dibutuhkan untuk kepentingan peneitian ini.

\section{REFERENSI}

Abdullah, F. H., Majid, N. H. A., \& Othman, R. (2016). Defining Issue of Thermal Comfort Control through Urban Mosque Façade Design. Procedia - Social and Behavioral Sciences. https://doi.org/10.1016/j.sbspro.2016.10. 259

Amin, M. (2004). pengaruh bukaan terhadap kenyamanan thermal pada bangunan publik di daerah tropis. 2.

Damastuti, N., \& Nasihien, R. D. (2017). Simulasi Kecepatan Angin dengan CFD Untuk Mengetahui Tingkat Kenyamanan Thermal Masjid Narotama II-1 II-2. 9, $1-4$.

Karyono, T. H. (2000). Report on thermal comfort and building energy studies in Jakarta - Indonesia. Building and Environment.

https://doi.org/10.1016/S0360-
1323(98)00066-3

Keputusan Menteri Kesehatan Nomor 261/MENKES/SK/II/1998 Tentang :

Persyaratan Kesehatan Lingkungan

Kerja. (1998). Keputusan Menteri

Kesehatan Nomor

261/MENKES/SK/II/1998 Tentang :

Persyaratan Kesehatan Lingkungan

Kerja. (261), 1-12.

Lestari, D. S. S. (2013). KONDISI KENYAMANAN THERMAL BANGUNAN GEREJA BLENDUK SEMARANG. Architecture.

Othman, R., \& Zainal-Abidin, Z. J. (2011). The importance of Islamic art in mosque interior. Procedia Engineering, 20, 105109.

https://doi.org/10.1016/j.proeng.2011.11 .144

Rony, R. (2014). Ikonografi Arsitektur dan Interior Masjid Kristal Khadija Yogyakarta. Journal of Urban Society's Arts. https://doi.org/10.24821/jousa.v1i2.793

Soegijanto. (1999). Bangunan di Indonesia dengan Iklim Tropis Lembab Ditinjau dari Aspek Fisika Bangunan (Buildings in Indonesia with the Humid Tropical Climate Considering Building Physics Aspects). Retrieved from http://ailis.lib.unair.ac.id/opac/detailopac?id=1034

Sutrisno, A. F., Prijadi, R., Prodi, M., Arsitektur, S., Teknik, F., Ratulangi, U. S., ... Ratulangi, U. S. (2013). MEDIA MATRASAIN. 10(2), 10-19.

Webb, M. (2013). Building Energy and Cfd Simulation To Verify Thermal Comfort in Under Floor Air Distribution ( Ufad ) Design. Building Simulation. 


\section{LAMPIRAN GAMBAR DAN TABEL}

\section{A. LAMPIRAN GAMBAR}

1. Masjid era Raja Safawi Abbas I

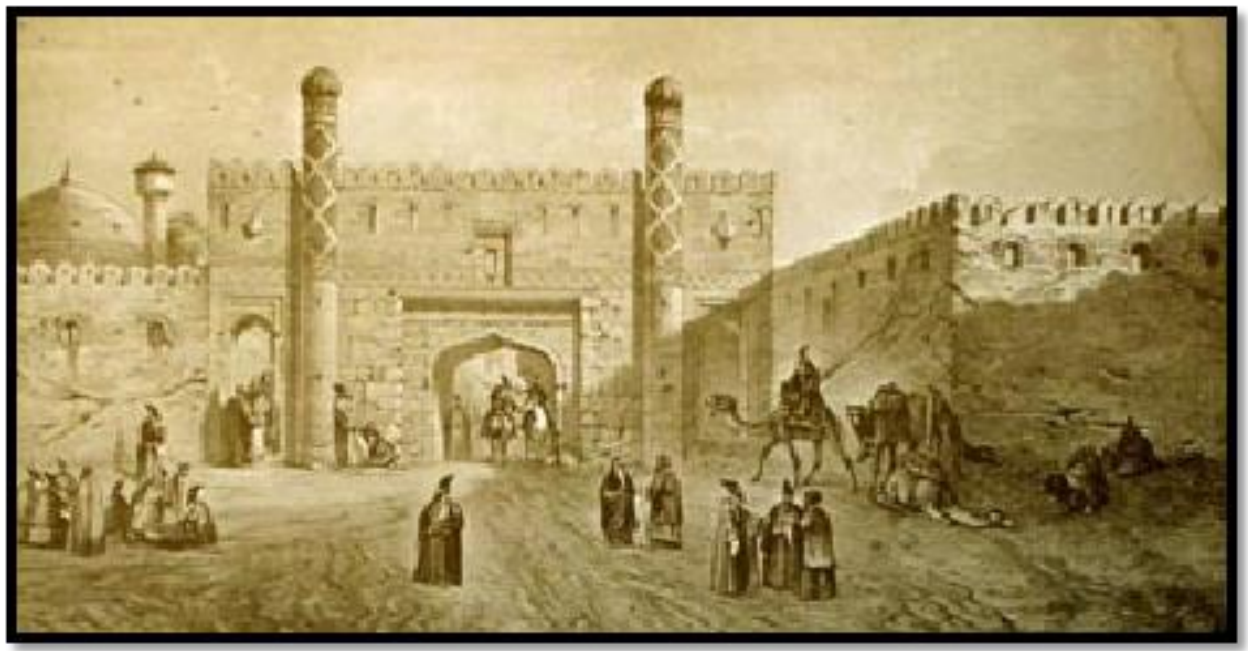

2. Site Plan Masjid Al-Fairus

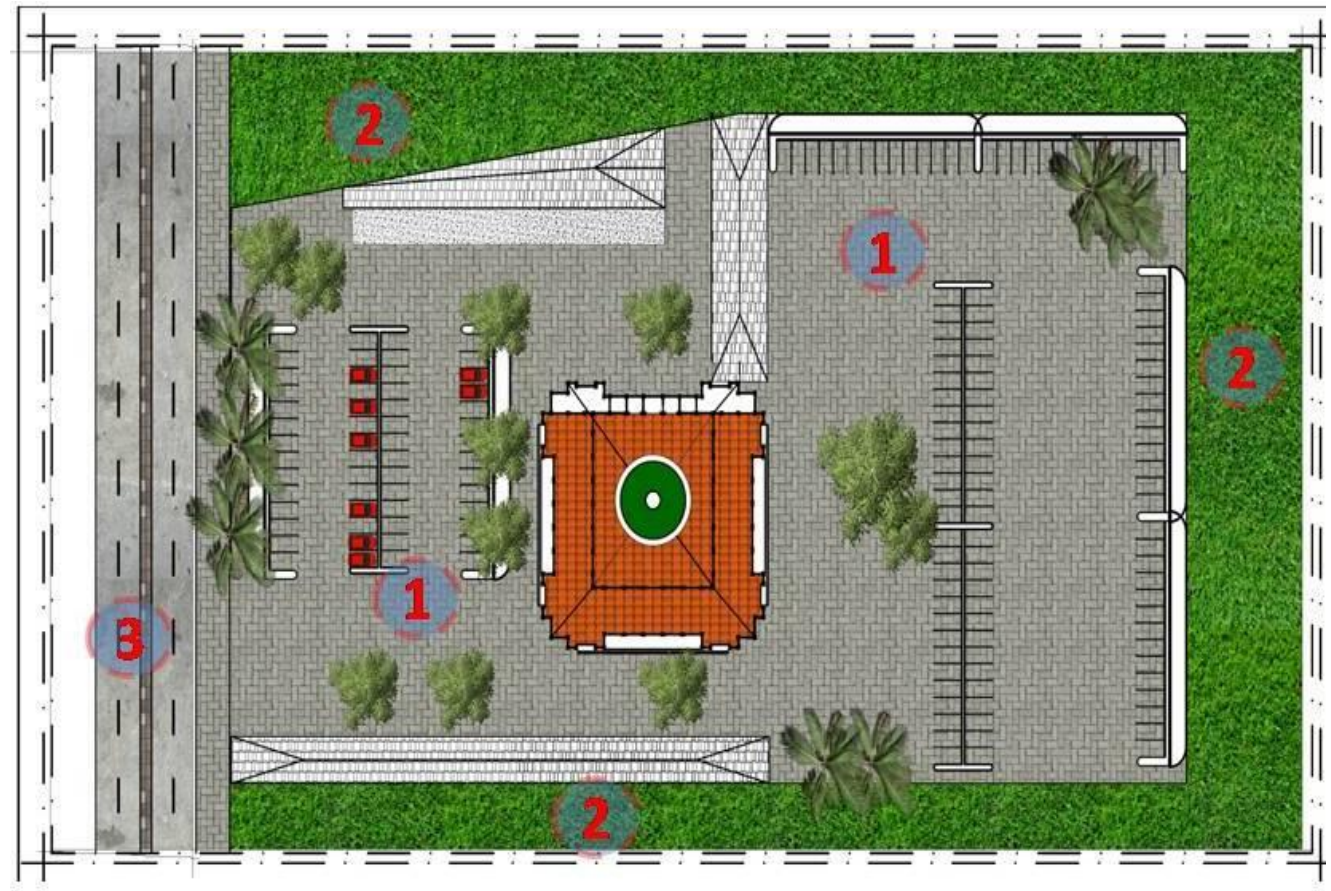

1. AREA PARKIR

2. AREA PERSAWAHAN

3. JALAN RAYA 
3. Kondisi Area Luar Masjid Al-Fairus

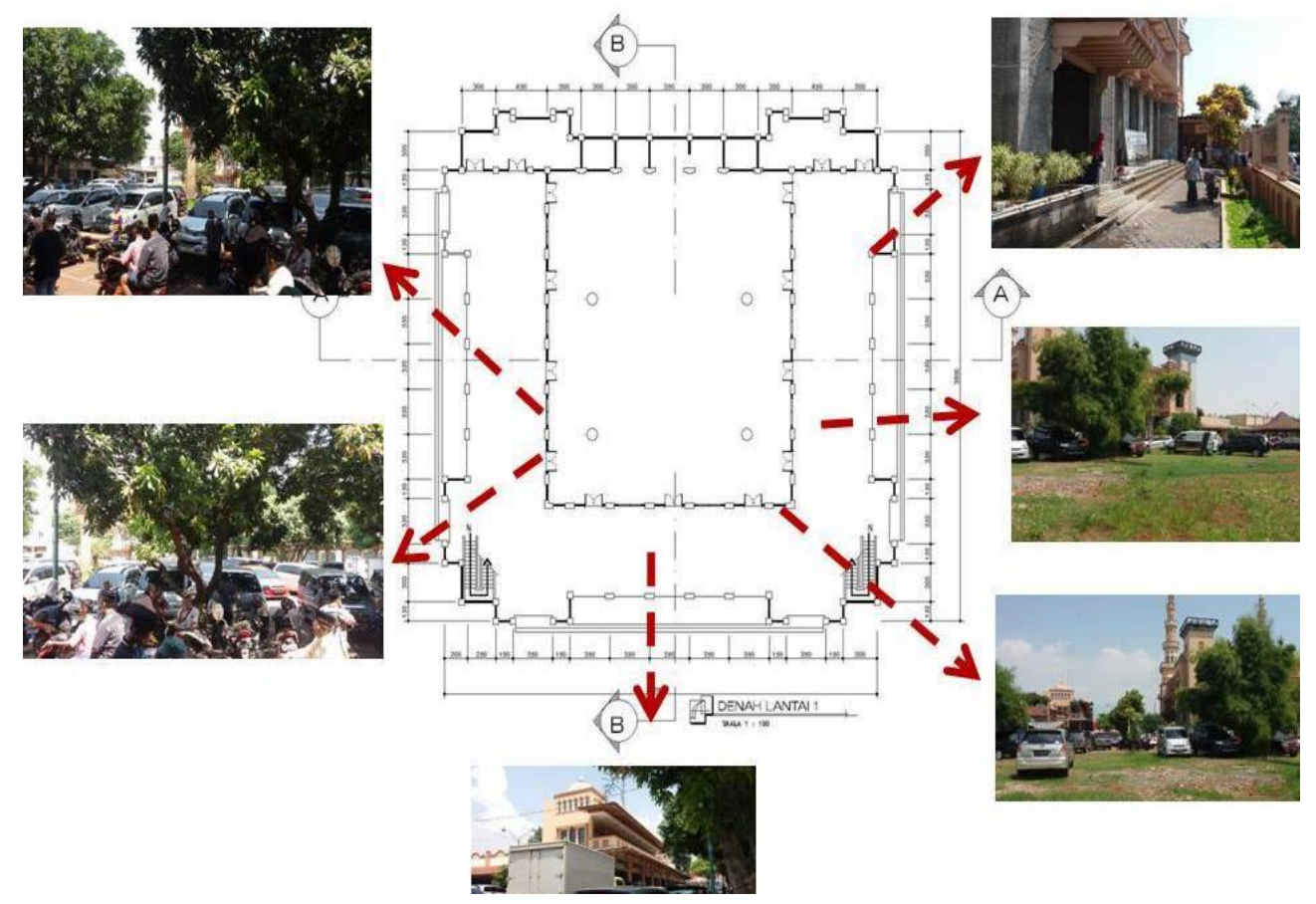

4. Kondisi Area Dalam Masjid Al-Fairus

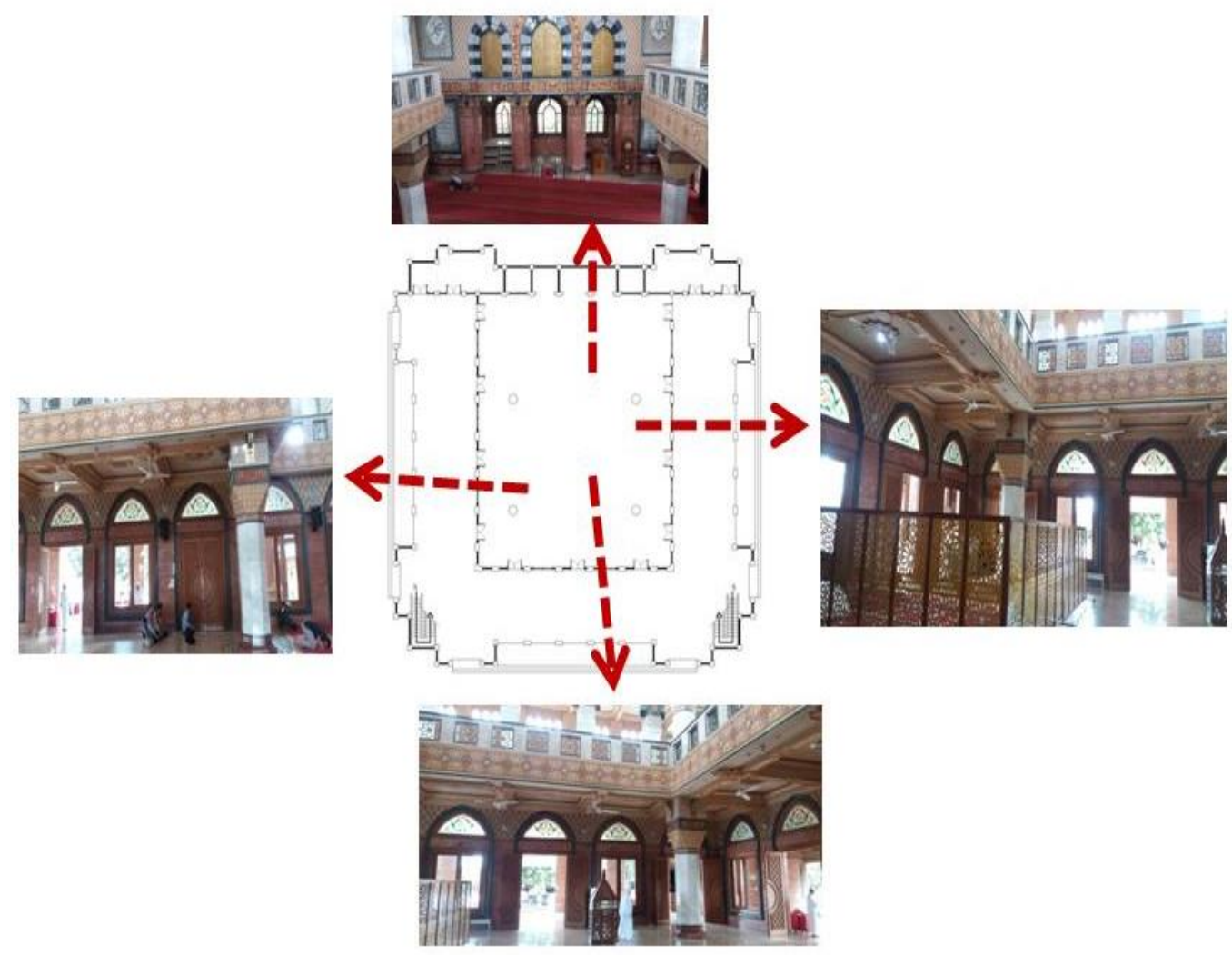


5. Lokasi Titik Ukur

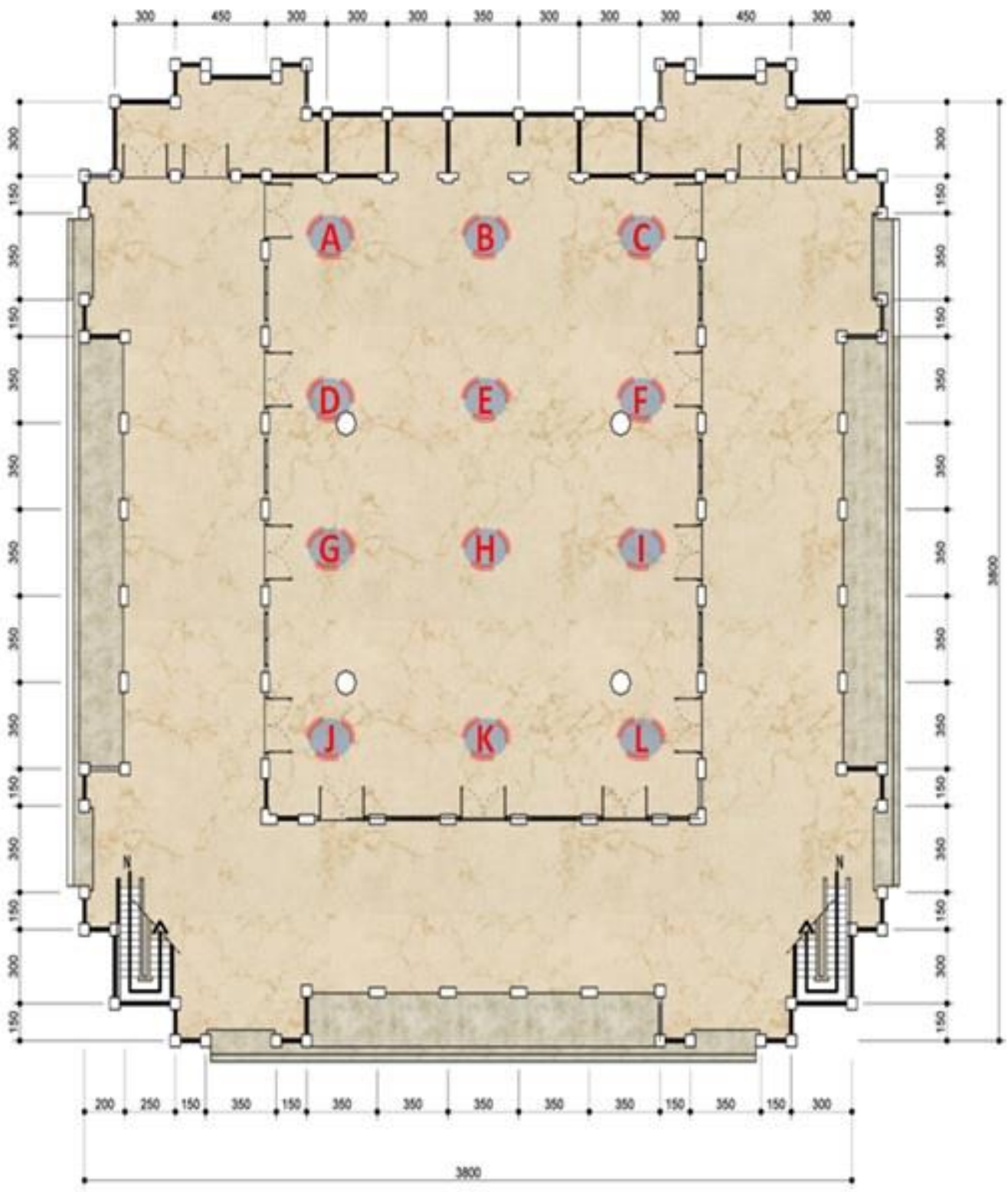




\section{B. LAMPIRAN TABEL \& GRAFIK}

1. Tabel Suhu Efektif Masjid Al-fairus Tanpa Ada Aktifitas Ibadah Pukul 10.00 WIB

\begin{tabular}{|c|c|c|c|c|c|}
\hline \multirow{2}{*}{ TITIK } & \multicolumn{5}{|c|}{ Temperatur Efektif (TE) ${ }^{\circ}$ C } \\
\cline { 2 - 6 } & 08.00 & 09.00 & 10.00 & 14.00 & 16.00 \\
\hline A & 26.03 & 26.72 & 26.22 & 26.86 & 25.61 \\
\hline B & 26.03 & 26.58 & 26.28 & 27.31 & 25.95 \\
\hline C & 26.06 & 26,80 & 26.74 & 26.39 & 25.20 \\
\hline D & 26.16 & 26.72 & 26.42 & 26.96 & 26.03 \\
\hline E & 26.03 & 26.72 & 27.72 & 27.61 & 26.18 \\
\hline F & 25.94 & 26.69 & 26.03 & 26.99 & 25.65 \\
\hline G & 26.03 & 26.72 & 26.72 & 26.97 & 25.56 \\
\hline H & 26.03 & 26.72 & 26.54 & 27.31 & 26.32 \\
\hline I & 26.3 & 26.44 & 26.44 & 26.78 & 25.59 \\
\hline J & 26.09 & 26.80 & 27.80 & 26.99 & 26.18 \\
\hline K & 25.90 & 26.69 & 26.69 & 28.12 & 26.27 \\
\hline L & 25,83 & 26.35 & 26.35 & 26.75 & 25.70 \\
\hline
\end{tabular}

2. Tabel Pergerakan Udara Masjid Alfairus Tanpa Ada Aktifitas Ibadah Pukul 10.00 WIB

\begin{tabular}{|c|c|c|c|c|c|c|}
\hline \multirow{2}{*}{ TITIK UKUR } & \multicolumn{5}{|c|}{ Pergerakan Udara $(\mathrm{m} / \mathrm{s})$} & Arah Angin \\
\hline & 08.00 & 09.00 & 10.00 & 14.00 & 16.00 & \multirow{13}{*}{ 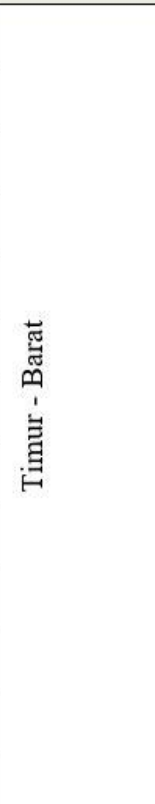 } \\
\hline A & 0.06 & 0.07 & 0.11 & 0.45 & 0.42 & \\
\hline B & 0.07 & .0 .06 & 0.09 & 0.33 & .0 .30 & \\
\hline $\mathrm{C}$ & 0.14 & 0.12 & 0.04 & 0.77 & 0.72 & \\
\hline $\mathrm{D}$ & 0.10 & 0.09 & 0.07 & 0.41 & 0.38 & \\
\hline $\mathrm{E}$ & 0.05 & 0.10 & 0.05 & 0.24 & 0.29 & \\
\hline $\mathrm{F}$ & $0 . .09$ & 0.14 & 0.14 & 0.40 & 0.45 & \\
\hline G & $0 . .09$ & 0.11 & 0.06 & 0.37 & 0.49 & \\
\hline $\mathrm{H}$ & 0.05 & 0.08 & 0.08 & 0.33 & 0.26 & \\
\hline I & 0.09 & 0.17 & 0.17 & 0.49 & 0.51 & \\
\hline $\mathrm{J}$ & 0.10 & 0.10 & 0.04 & 0.33 & 0.29 & \\
\hline $\mathrm{K}$ & 0.16 & 0.14 & 0.14 & 0.15 & 0.27 & \\
\hline $\mathrm{L}$ & 0.17 & 0.19 & 0.19 & 0.41 & 0.43 & \\
\hline
\end{tabular}


3. Tabel Suhu Efektif Masjid Al-fairus Saat Sholat Jumat.

\begin{tabular}{|c|c|c|c|c|c|c|}
\hline \multirow{2}{*}{$\begin{array}{c}\text { TITK } \\
\text { UKUR }\end{array}$} & \multicolumn{6}{|c|}{ Temperatur Efektif (TE) ${ }^{\circ} \mathrm{C}$} \\
\cline { 2 - 7 } & Dzuhur & Ashar & Magrib & Isya & Shubuh & Jumat \\
\hline A & 26.03 & 26.72 & 26.78 & 26.86 & 25.61 & 31.80 \\
\hline B & 26.03 & 26.58 & 26.80 & 27.31 & 25.95 & 32.00 \\
\hline C & 26.06 & 26,80 & 26.01 & 26.39 & 25.20 & 31.80 \\
\hline D & 26.16 & 26.72 & 26.94 & 26.96 & 26.03 & 31.80 \\
\hline E & 26.03 & 26.72 & 27.00 & 27.61 & 26.18 & 32.20 \\
\hline F & 25.94 & 26.69 & 26.16 & 26.99 & 25.65 & 31.53 \\
\hline G & 26.03 & 26.72 & 26.24 & 26.97 & 25.56 & 31.48 \\
\hline H & 26.03 & 26.72 & 27.23 & 27.31 & 26.32 & 32.14 \\
\hline I & 26.3 & 26.44 & 26.38 & 26.78 & 25.59 & 31.22 \\
\hline J & 26.09 & 26.80 & 27.06 & 26.99 & 26.18 & 31.42 \\
\hline K & 25.90 & 26.69 & 26.44 & 28.12 & 26.27 & 31.58 \\
\hline L & 25,83 & 26.35 & 26.85 & 26.75 & 25.70 & 31.34 \\
\hline
\end{tabular}

4. Tabel Pergerakan Udara Masjid Alfairus Saat Sholat Jumat

\begin{tabular}{|c|c|c|c|c|c|c|}
\hline \multirow{2}{*}{$\begin{array}{l}\text { Titik } \\
\text { Ukur }\end{array}$} & \multicolumn{5}{|c|}{ Pergerakan Udara $(\mathrm{m} / \mathrm{s})$} & Arah \\
\hline & Ashar & Magrib & Isya & Shubuh & Jumat & \multirow{13}{*}{ 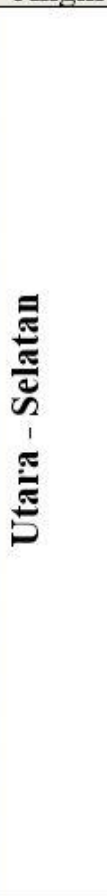 } \\
\hline A & 0.67 & 0.14 & 0.28 & 0.17 & 0.53 & \\
\hline B & .0 .81 & 0.11 & 0.28 & .0 .22 & 0.39 & \\
\hline C & 1.01 & 0.07 & 0.31 & 0.27 & 0.94 & \\
\hline D & 0.57 & 0.18 & 0.28 & 0.09 & 0.43 & \\
\hline E & 0.24 & 0.11 & 0.11 & 0.09 & 0.28 & \\
\hline $\mathrm{F}$ & 0.57 & 0.37 & 0.30 & 0.06 & 0.56 & \\
\hline G & 0.24 & 0.16 & 0.21 & 0.25 & 0.35 & \\
\hline $\mathrm{H}$ & 0.37 & 0.07 & 0.06 & 0.10 & 0.19 & \\
\hline I & 0.50 & 0.26 & 0.23 & 0.06 & 0.40 & \\
\hline $\mathrm{J}$ & 0.28 & 0.26 & 0.22 & 0.15 & 0.51 & \\
\hline $\mathrm{K}$ & 0.45 & 0.27 & 0.24 & 0.08 & 0.59 & \\
\hline L & 0.47 & 0.26 & 0.28 & 0.17 & 0.53 & \\
\hline
\end{tabular}


5. Grafik Hubungan Suhu Efektif dan Pergerakan Udara Saat Tidak Ada Aktifitas Ibadah

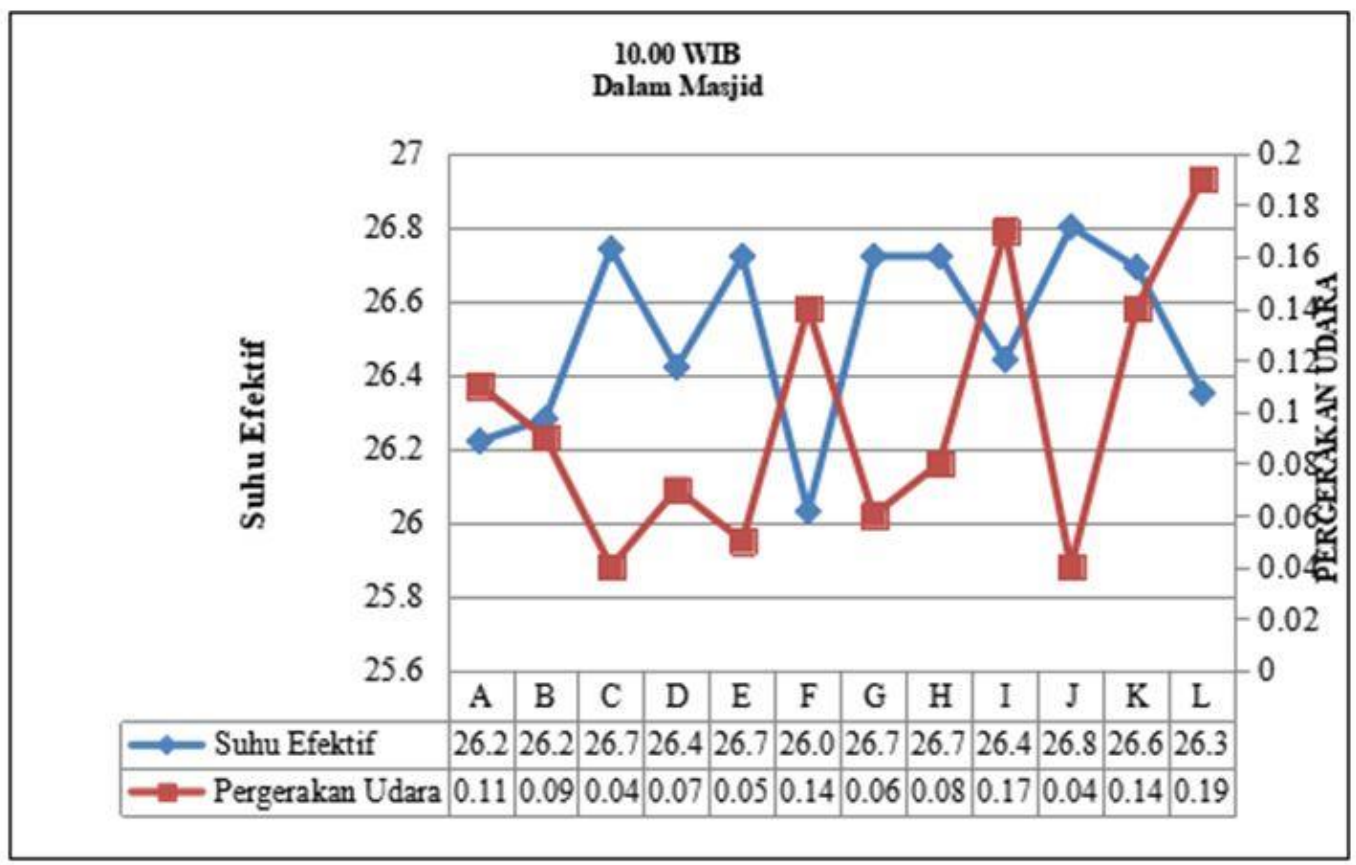

6. Grafik Hubungan Suhu Efektif dan

Pergerakan Udara Saat Sholat Jumat

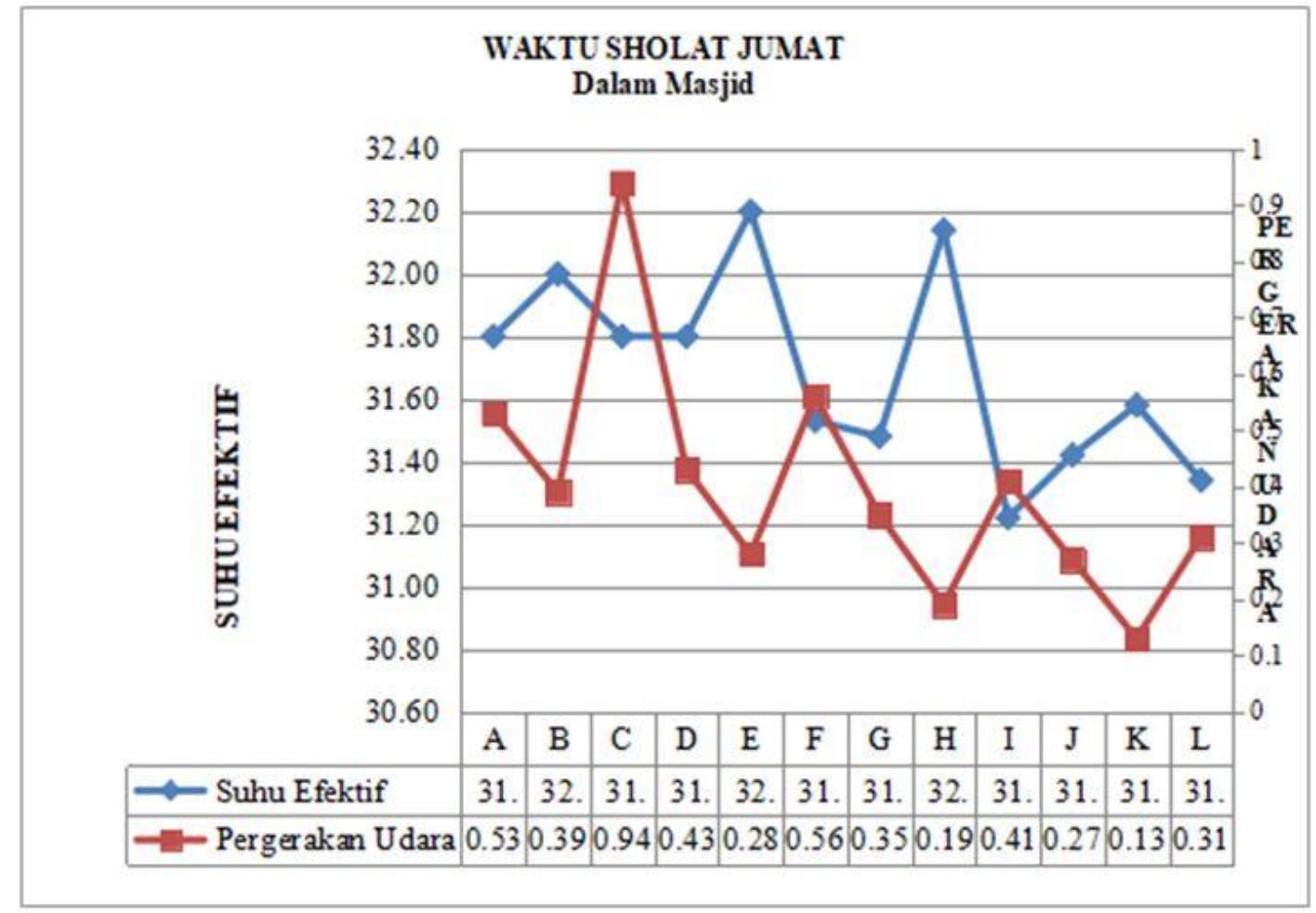

